\title{
USING A DISCONTINUOUS GRANT RULE TO IDENTIFY THE EFFECT OF GRANTS ON LOCAL TAXES AND SPENDING
}

\author{
MATZ DAHLBERG \\ EVA MÖRK \\ JøRN RATTS \\ HANNA ÅGREN
}

CESIFO WORKING PAPER NO. 1857

CATEgORY 1: PubliC FinANCE

NOVEMBER 2006

An electronic version of the paper may be downloaded

- from the SSRN website:

- from the RePEc website:

- from the CESifo website:

www.SSRN.com

www.RePEc.org

www.CESifo-group.de 


\title{
USING A DisCONTINUOUS GRANT RULE TO IDENTIFY THE EFFECT OF GRANTS ON LOCAL TAXES AND SPENDING
}

\begin{abstract}
When investigating the effects of federal grants on the behavior of lower-level governments, it is hard to defend the handling of grants as an exogenous factor affecting local governments; federal governments often set grants based on characteristics and performance of local governments. In this paper we make use of a discontinuity in the Swedish grant system in order to estimate the causal effects of general intergovernmental grants on local spending and local tax rates. The formula for the distribution of funds is used as an exclusion restriction in an IV-estimation. We find evidence of crowding-in, where federal grants are shifted to more local spending, but not to reduced local tax rates. Our results thus confirm a flypaper effect for Sweden.
\end{abstract}

JEL Code: H21, H71, H77, R51.

Keywords: fiscal federalism, grants, flypaper effect, local taxation, local government expenditure, causal effects.

$$
\begin{gathered}
\text { Matz Dahlberg } \\
\text { Department of Economics } \\
\text { Uppsala University } \\
\text { P.O. Box } 513 \\
\text { Sweden - 75120 Uppsala } \\
\text { matz.dahlberg@nek.uu.se } \\
\text { Jørn Rattsø } \\
\text { Department of Economics } \\
\text { Norwegian University of Science and } \\
\text { Technology } \\
\text { Norway - 7491 Trondheim } \\
\text { jorn.rattso@svt.ntnu.no }
\end{gathered}
$$

\author{
Eva Mörk \\ Department of Economics \\ Uppsala University \\ P.O. Box 513 \\ Sweden - 75120 Uppsala \\ eva.mork@nek.uu.se \\ Hanna Ågren \\ Department of Economics \\ Uppsala University \\ P.O. Box 513 \\ Sweden - 75120 Uppsala \\ hanna.agren@nek.uu.se
}

November 2006

We appreciate financing from the Norwegian Research Council and from the Swedish Association of Local Authorities. The paper has benefited from discussions with Per Pettersson-Lidbom and Björn Öckert and from comments from seminar participants at Uppsala University, participants at the 2006 Norwegian Research Forum on Taxation in Holmsbu, Norway, and participants at the 2006 IFIR-CESifo conference on New Directions in Fiscal Federalism in Lexington, Kentucky. A special thank to our discussants Rolf Aaberge and Albert Solé- Ollé. Heléne Lundqvist provided excellent research assistance. The responsibility for any shortcomings remains with us. 


\section{Introduction}

A key issue in the design of fiscal federalism is the financing of lower-level governments. Because of the advantages of taxation at the federal level and spending at the decentralized level most countries end up with vertical fiscal imbalance. The decentralization of expenditure is typically not accompanied by equivalent revenue-raising responsibilities. Hence, there is an imbalance between where the money is spent and where revenues are collected.

Intergovernmental grants consequently are an important part of the financing of decentralized government.

Although grants from the federal government primarily substitute for decentralized taxes, they are also motivated by equalization and earmarking. Understanding how these grants affect decentralized governmental behavior is of interest not only for the federal decision maker. In the basic median voter model of local public finance, grant revenue is treated as any other income in the community. Grants are expected to be allocated between local public and private goods in accordance with the income elasticities of the median voter. This insight was originally offered by Scott (1952) and Bradford and Oates (1971a,b). Federal government grants to decentralized governments will then to a large extent be handed out to the local population as reduced taxes and fees, since the decentralized governments already have arranged an optimal mix of local public goods and private consumption. However, the empirical literature has never given much support to this theory prediction. Already Gramlich (1977) summarized the empirical finding that grants tend to expand spending with the same amounts. ${ }^{1}$ Arthur Okun is credited with the term 'flypaper effect', since 'money stick where they hit' i.e. that grants never leave the state budget and enter into the personal wallets through lower local taxes. In a modern restatement, Knight (2002) defines the two approaches as crowding-out versus crowding-in; the flypaper effect implies that federal grants crowd in local spending whereas, in the median voter framework, federal grants crowd out local spending dollar for dollar after accounting for income effects.

One explanation for the somewhat puzzling lack of evidence for the median voter model might be a methodological flaw of earlier empirical studies. When the federal decision making of grants is addressed, it is hard to defend the handling of grants as an exogenous

\footnotetext{
${ }^{1}$ See Hines and Thaler (1995) for a more recent overview.
} 
factor affecting local governments. ${ }^{2}$ However, only few studies make attempts at handling the endogeneity of federal grants. Two recent studies, that have been given some attention, are Knight (2002) and Gordon (2004). ${ }^{3}$ Knight (2002) presents a theoretical model where legislative bargaining over grants predicts a positive correlation between grant receipts and preferences for public goods. In order to solve this endogeneity the empirical part applies instruments based on the political power of congressional delegations to account for the exogenous part of grants variation related to highway spending in the US. Knight concludes that the endogeneity can explain the flypaper effect. His estimates indicate that grants crowd out highway spending when the policy endogeneity is accounted for. Gordon (2004) applies the underlying change in data of the criteria of block grants to identify the causal effect. She takes advantage of the updating of data for key criteria in the grants allocation to school districts in the US. The updating of data given in the 1990 census leads to a discontinuous change in the grants distributed. The census-determined change in grants is calculated and used as an instrument for the actual change of grants. The spending demand effect of the demographic 'shift' is taken into account by assuming constant per-pupil spending. The estimated results show strong crowding-in (flypaper effect) during the first year of the new grants distribution.

The studies by Knight and Gordon are welcomed contributions to the literature. However, their studies concern very specific grant programs (highway spending and Title 1) under the US setting. It is likely that different grant programs may have different effects and that the results may be sensitive to the economic setting. Hence, we still know very little about the causal effects of grants on lower level governmental behavior. Furthermore, Knight's choice of instrumental variables based on politics has some weaknesses. The proportion of state delegation serving on the transportation authorization committee is used as an instrument. If delegates typically serve in committees according to their preferences, this may not be exogenous to highway spending. The second instrument is the proportion of a state's representatives in the majority party. Given that the majority party is the same during long time periods, this is clearly a variable that captures preferences of the voters in the state. ${ }^{4}$

\footnotetext{
${ }^{2}$ The problem of estimating incidence of endogenous policies was pointed out by Besley and Case (2000).

${ }^{3}$ Instrumentation of federal grants has been applied in US-studies by Becker (1996), Gamkhar and Oates (1996), and Turnbull (1998), while Berg and Rattsø (2006) take advantage of a tax reform changing the distribution of grants in Norway.

${ }^{4}$ Also, looking at Knight's first step estimates (see columns 3 in Table 3 in Knight) there are two reasons to worry. First, the F-test for the instrumental variables is very low (around 2.6 with 5 degrees of freedom). Second, the instruments have different signs depending on if they are measured at the House or at the Senate level.
} 
The aim of this paper is to add to the existing literature studying the causal effects of unconditional block (lump sum) grants on local spending and taxes in Sweden. In order to identify the causal effect of grants we follow Guryan (2003) and make use of a discontinuity in the Swedish grant formula where municipalities with a net out-migration above two percent receive grants whereas municipalities with a net out-migration below two percent do not. This formula for the distribution of funds is used as an exclusion restriction in an IV-estimation where the identifying assumption is that the functional form of the direct relationship between the dependent variable and the treatment-determining covariates is not the same as the functional form of the relationship between treatment-determining covariates and grants. ${ }^{5}$ Our approach is in some ways similar to the one adopted by Gordon in that that she uses a discontinuous change in the grant formula. However, whereas she uses a discontinuity that exists every tenth year, our discontinuity is observed each year between 1996 and 2004. We thus have a panel of 284 municipalities observed over nine years. We find evidence of crowding-in, where federal grants are shifted to more local spending, but not reduced local taxes. Our results thus confirm a flypaper effect for Sweden.

The outline of the paper is the following: the sources of grant endogeneity is laid out in section 2. Section 3 presents the grant formula that is used to identify the effects of intergovernmental grants on local spending and tax rate. Section 4 discusses our identification strategy building on the use of the grant formula in instrumentation. Data, as well as some descriptive analysis of the Swedish system, are presented in section 5. Estimated causal effects on local spending and taxation are shown in section 6. Finally, section 7 offers concluding remarks.

\section{Sources of grant endogeneity}

The background understanding of grant endogeneity can be described in a simple model of political decision making suggested by Besley and Case (2000) in an article discussing endogenous policies as right hand side variables. In econometric terms, the endogeneity is an omitted variables story. Assume that we want to estimate the effect of block grants on local government spending and taxation, where $\mathrm{Y}$ measures local public spending and taxation, $\mathbf{X}$ is

\footnotetext{
${ }^{5}$ That is, the variable that determines grants may also affect spending, as long as the way it affects spending differs.
} 
a vector of local socio-economic variables that might explain local spending and taxation, and $\mathrm{P}$ (the policy) is central government block grants. Assume that $\mathrm{P}$ is a function of local socioeconomic variables other than $\mathbf{X}$, say $\mathbf{Q}$, and political variables, $\mathbf{W}$. $\mathbf{Q}$ and $\mathbf{W}$ are typically not controlled for in the estimation of local spending and taxation equations. Given this general set-up, Besley and Case show that the probability limit of the OLS estimate of the coefficient for the grant variable has two sources of bias (their equation 10):

1. Omitted variable bias caused by observable variables that determine policy and that have independent influence on the outcome of interest (i.e., $\mathbf{Q}$ and $\mathbf{W}$ )

2. Bias due to the presence of unobservable variables that may determine both the policy and the outcome of interest.

There are at least four cases where we can suspect a bias when investigating the effects of central government block grants on local governments spending and taxes:

(i) Political variables, $\mathbf{W}$, might matter because the grant system is designed in negotiations between central politicians representing different local regions, or between central and local politicians, which implies that preferences for local spending and grants distribution will be correlated (this is along the lines of the Knight, 2002, story).

(ii) Even in the absence of negotiations, political variables, $\mathbf{W}$, might matter because central politicians designing the grant system have preferences for specific economic and/or political characteristics of the municipalities associated with their spending priorities. In this case the grant variable is endogenous in a spending equation (the argument that the central government designs the grant system with an eye on the characteristics of the municipalities is developed by Johansson, 2003).

(iii) Independent of the role of political variables, local socio-economic characteristics of the municipality, $\mathbf{Q}$, might matter. It might be the case that not all variation in the grant variable is exogenous to local spending because some local socio-economic variable(s) influence both spending and taxation and the way grants are allocated. It is hard to control for all variables that might be correlated both with local 
spending and taxation and with grant allocation (for a related discussion, see Gordon, 2004).

(iv) Unobserved characteristics that can be correlated with both local spending and with grant allocation might be important.

\section{The grant formula used for identification}

In this paper we will use an element in the cost equalizing grant formula ${ }^{6}$ that can be applied as a source of exogenous variation in the grants, namely a component that is intended to support municipalities with a negative population growth. The grants come with no strings attached, that is, municipalities can use the money in the way they prefer. Grants are distributed to local governments with a net out-migration larger than two percent the last ten years (with a two-year lag). More formally, municipality $i$ receives out-migration grants in year $t\left(g_{i t}^{m}\right)$ according to the following rule:

(1)

$$
g_{i t}^{m}\left\{\begin{array}{l}
>0 \text { if } m_{(i t-2)-(i t-12)}>2 \\
=0 \text { if } m_{(i t-2)-(i t-12)} \leq 2
\end{array},\right.
$$

where $m_{(i t)-(i t-j)}$ is the net out-migration rate in municipality $i$ between year $t$ and year $j$. The amount of out-migration grants received is proportional to the out-migration rate. Figure 1 plots grants received by the municipalities against the rule for a typical year (1999). As can be seen from the figure, there is a well-defined cut at two percent where municipalities with lower net out-migration than two percent do not receive any grants whereas municipalities above two percent receive grants. ${ }^{7}$

\footnotetext{
${ }^{6}$ The cost equalizing grant is a block grant to support municipalities that are characterized by demographic and other structural conditions associated with higher costs.

${ }^{7}$ The block grant is self-financed and the total cost for this grant component is divided equally (per capita) between all municipalities.
} 
Figure 1 Out-migration grants (SEK/capita) against net out-migration, 1999

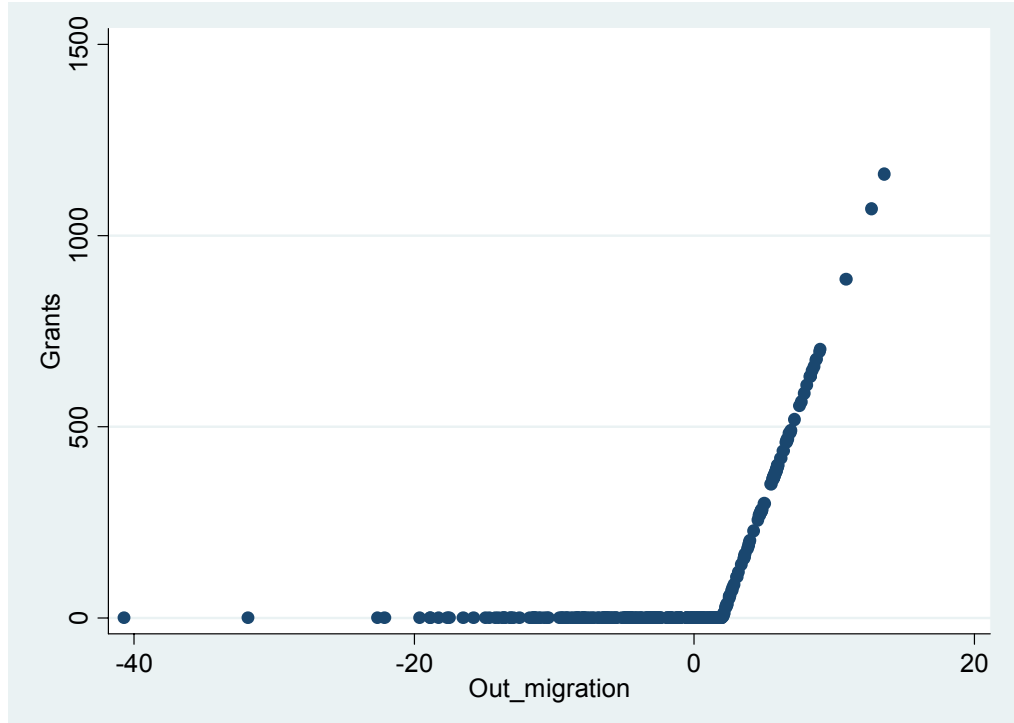

In the year 2000, an additional compensation in the form of grants was introduced to take into account the change in the number of school-age children. This compensation was conditioned on the net out-migration rate during the past three years (with a two year lag, $m_{(i t-2)-(i t-5)}$ ), which had to be larger than two percent. More formally, municipality $i$ receives additional out-migration grants in year $t\left(g_{i t}^{m, s}\right)$ according to the following rule:

(2) $g_{i t}^{m, s}\left\{\begin{array}{l}>0 \text { if } s_{(i t-2)-(i t-5)}<0 \text { and } m_{(i t-2)-(i t-5)}>2, \\ =0 \text { otherwise }\end{array}\right.$,

where $s_{(i t)-(i t-j)}$ is the net change in the number of school-age children in municipality $i$ between year $t$ and year $j .{ }^{8}$ Both these elements will be used in our identification strategy discussed below.

\section{Identification strategy using the discontinuous grant rule}

We are interested in the causal effect of block grants on local government spending and local tax rates, i.e., the relationship we want to identify is given by

$$
y_{i t}=\alpha_{0}+\alpha_{1} g_{i t}+\varepsilon_{i t},
$$

\footnotetext{
${ }^{8}$ During 2000-2001, this compensation was based on changes in the age group 7-15 and in 2002-2004 on changes in the age group 7-18.
} 
where $y$ is spending or taxes and $g$ is intergovernmental block grants. However, if we estimate the equation directly our estimated parameters will be biased for at least two reasons. First, there is the obvious problem of omitted variables. Second, as argued earlier, grants are likely to be endogenous. Below we will focus on how we solve the endogeneity problem. ${ }^{9}$

To solve the endogeneity problem, we propose using an instrumental variables (IV) estimator, where the formula for the out-migration grant $\left(\Omega\left(m_{(i t-2)-(i t-12)}, s_{(i t-2)-(i t-5)}\right)\right)$ is used as an excluded instrument. ${ }^{10}$ Since $m_{(i t-2)-(i t-12)}$ and $s_{(i t-2)-(i t-5)}$ might have a direct effect on the outcome of main interest (i.e., on local spending and local taxes) we need to control for these variables directly in the estimations; otherwise the instrument will not be valid. Since we do not know the exact form of this direct effect we allow for as flexible functional form as possible. This implies that the first stage in the two-stage least squares procedure is given by

$$
g_{i t}=\gamma_{0}+\gamma_{1} \Omega\left(m_{(i t-2)-(i t-12)}, s_{(i t-2)-(i t-5}\right)+\phi^{\prime} f\left(m_{(i t-2)-(i t-12)}\right)+\theta^{\prime} h\left(s_{(i t-2)-(i t-5}\right)+\eta_{i t},
$$

where $f(\cdot)$ and $h(\cdot)$ are smooth functions of the treatment-determining covariates, and that the second step (where the relationship of main interest is estimated) is given by

$$
y_{i t}=\alpha_{0}+\alpha_{1} \hat{g}_{i t}+\delta^{\prime} f\left(m_{(i t-2)-(i t-12)}\right)+\lambda^{\prime} h\left(s_{(i t-2)-(i t-5}\right)+\varepsilon_{i t},
$$

where $\hat{g}$ is the predicted grants obtained from the estimation of equation (4). ${ }^{11}$

The exclusion restriction that is required for the suggested instrument to be valid is that the functional form of the direct relationship between local spending or local taxes and the

\footnotetext{
${ }^{9}$ Since our suggested procedure estimates direct causal effect, omitted variable bias is not a concern. This assumption will be examined when testing for instrument validity. See below for more details.

${ }^{10}$ A similar approach is taken by Guryan (2003) when estimating the effect of school spending on students' test scores. The grant nonlinearity can possibly be analyzed by the regression-discontinuity method (see, e.g., Angrist and Lavy, 1999; Hahn et al., 2001; and Lee, 2005). However, the grant formula used in this paper differs from a classical regression discontinuity design in two aspects. First, there is no "jump" in treatment at the cutpoint. Second, all treated do not receive the same amount, but the grants are proportional to treatment-determining variables (net out-migration and net change in school-aged children). Future research may allow us to study this using a regression-discontinuity approach with continuous treatment depending on covariates.

${ }^{11}$ In the estimations, we use up to a fourth-order polynomial in the smooth functions $f(\cdot)$ and $h(\cdot)$.
} 
treatment-determining covariates (as given by the smooth functions in net out-migration and in net change in the number of school-age children) is not the same as the functional form of the relationship between treatment-determining covariates and grants (described by the discontinuous out-migration grant formula, i.e. the selection mechanism).

When specifying the control functions, we will use two different approaches. In the first, and perhaps most direct approach, we will follow the specifications given in equations (4) and (5) and include the net out-migration rate and the net change in the number of school-age children as separate variables in the control functions. An advantage with this approach is that the fact that the allocation formula changed in the year 2000 (to include the migration of school-age children) can potentially help us in identifying the effect we are looking for. ${ }^{12}$ However, when using high-order polynomials, we end up with a large number of covariates, potentially leading to too limited variation for identification of the parameter of main interest. In the second approach, we therefore construct a single variable based on the two rules determining grant assignment (given by equations (1) and (2)). The variable, which will be used in a single control function, is constructed as follows; when $g_{i t}^{m, s}=0 \quad$ (c.f. equation (2) above) the argument within parentheses in the control function is the net out-migration rate $\left(m_{(i t-2)-(i t-12)}\right)$, just as in $f(\cdot)$ above. When $g_{i t}^{m, s}>0$ the argument will instead be the sum of the net outmigration rate $\left(m_{(i t-2)-(i t-12)}\right)$ and the change in the number of school-age children $\left(s_{(i t-2)-(i t-5)}\right)$. This rule will be referred to as the composite rule.

We need to test the validity and the relevance of our suggested instrumental variable. The relevance of the excluded instrument can be examined by looking at the $t$-value for the coefficient on the excluded variable in the first-stage estimates. How to test for validity of the instrument is not obvious in our context. The model is not overidentified, which rules out tests for overidentifying restrictions (like the Sargan test). Another more indirect way of testing the validity has been suggested by Altonji et al. $(2002,2005)$. They suggest that the plausibility of exogeneity can be evaluated by testing whether the point estimates from the instrumental variable regression are sensitive to the inclusion of additional control variables. The idea is that if the estimates are insensitive to controlling for observables then they should also be

\footnotetext{
${ }^{12}$ The control functions are meant to capture the direct effects of the treatment-determining covariates on local spending and local tax rates. We argue that this direct effect is likely be the same before the year 2000 , when the grant formula was changed, and after. Therefore, the change in school-aged children will be included in the control function both before and after 2000.
} 
insensitive to unobservable determinants of the outcome variable, that is, the omitted variable bias is likely to be quite small. For this method to work in practice, the set of control variables must be powerful in the sense that they should pick up the most important confounding variables. In the context of the flypaper effect, the demographic structure, the share of foreign citizens and the tax base are perhaps the most important variables to control for given the responsibilities of the local governments in Sweden.

\section{Institutional background and data}

Decentralized government in Sweden is among the largest in the world, with a comprehensive range of responsibilities, notably for primary education, child care and care for the elderly. The tax available, a local proportional income tax, is to the full discretion of the local government decision-makers and generates the main source of local government revenue; about 60-70 percent of total current revenue. The rest is made up of fees and central government grants, where 15-20 percent of total revenues consist of grants. After the grant reform in 1993, block grants dominate. The grant system was slightly changed in 1996 and the block grant was separated into income equalization and cost equalization in addition to a general per capita grant, and some transitional regulations. The general objective criteria of the grant system primarily relate to the private income level and demographics (age structure of the population). More specifically, the cost equalization aims at reducing the differences in structural cost conditions across municipalities, whereas the purpose of income equalization is to bring per capita tax revenues close to the national average. The local income tax gives local governments considerable discretion in the financing. Local governments are for example able to distribute federal grants to the local population by way of reducing the income tax. Hence, both crowding-in and crowding-out are possible outcomes in the Swedish setting.

In this paper we use an unbalanced panel of 283 municipalities observed over the time period 1996-2004. ${ }^{13}$ The grant-formula that is used for identification is an element of the cost equalization grants specified to compensate for out-migration of the local governments. During the time period 1996-2004, the average out-migration grant as a fraction of total cost equalizing grants for eligible municipalities' amounts to around 14 percent.

\footnotetext{
${ }^{13}$ The dataset covers all municipalities except for four that were affected by consolidations (Nykvarn, Södertälje, Knivsta and Uppsala) and three that have responsibilities that the other municipalities do not have (Gotland, Malmö and Göteborg).
} 
As described in section 2, the municipalities with lower net out-migration than 2 percent do not receive any grants whereas municipalities above 2 percent receive grants. From year 2000 and forward there is also an extra compensation for those municipalities with a diminishing share of school-aged children. Over the studied period, 116 municipalities were never treated, 55 municipalities were treated all nine years and the remaining 112 municipalities received grants some, but not all years. Figure 2 shows the number of times the municipalities have been treated over the years. Table 1 gives summary statistics for the two grants variables (cost equalizing grants and migration grants, both measured per capita), the two dependent variables (local current spending, measured per capita, and the local tax rate) and the variables used in the control functions (net out-migration and change in population 7-18). As is clear from the table, the two outcome variables exhibits quite a large variation, reflecting the autonomy that the Swedish municipalities have in making their spending and taxing decisions. The negative minimum values of cost equalizing and migration grants reflect the fact that the grant system is self-financed. The table also presents the socio-economic variables used when testing the validity of the instruments (share of population in the age interval $0-6$, share of population in the age interval $7-15$, share of population aged 80 years or older, population size, the per capita tax base, and the share of foreign-born citizens).

Table 1 Summary statistics for the variables used in the empirical analysis.

\begin{tabular}{lcccc}
\hline Variable & Mean & St dev & Min & Max \\
\hline Spending & 38,027 & $7,303.8$ & 20,606 & 68,380 \\
Local tax rate & 21.08 & 1.21 & 14.86 & 23.79 \\
Cost equalizing grants & 523.1 & $2,437.8$ & $-3,471.0$ & 13,196 \\
Migration grants & 118.7 & 315.1 & -135.8 & 1577.2 \\
Net out-migration & 0.847 & 7.88 & -42.95 & 16.64 \\
Change in population 7-18 & 2.66 & 4.10 & -10.25 & 23.59 \\
Pop share 0-6 & 0.079 & 0.013 & 0.047 & 0.128 \\
Pop share 7-15 & 0.122 & 0.012 & 0.068 & 0.164 \\
Pop share 80+ & 0.054 & 0.014 & 0.012 & 0.091 \\
Population & 27,675 & 49,073 & 2,575 & 761,721 \\
Tax base & 105,963 & 19,163 & 69,399 & 256,754 \\
Share foreign born & 0.040 & 0.027 & 0.006 & 0.291 \\
\hline
\end{tabular}


Figure 2: Distribution of the number of times the municipalities have been treated with outmigration grants over the time period 1996-2004.

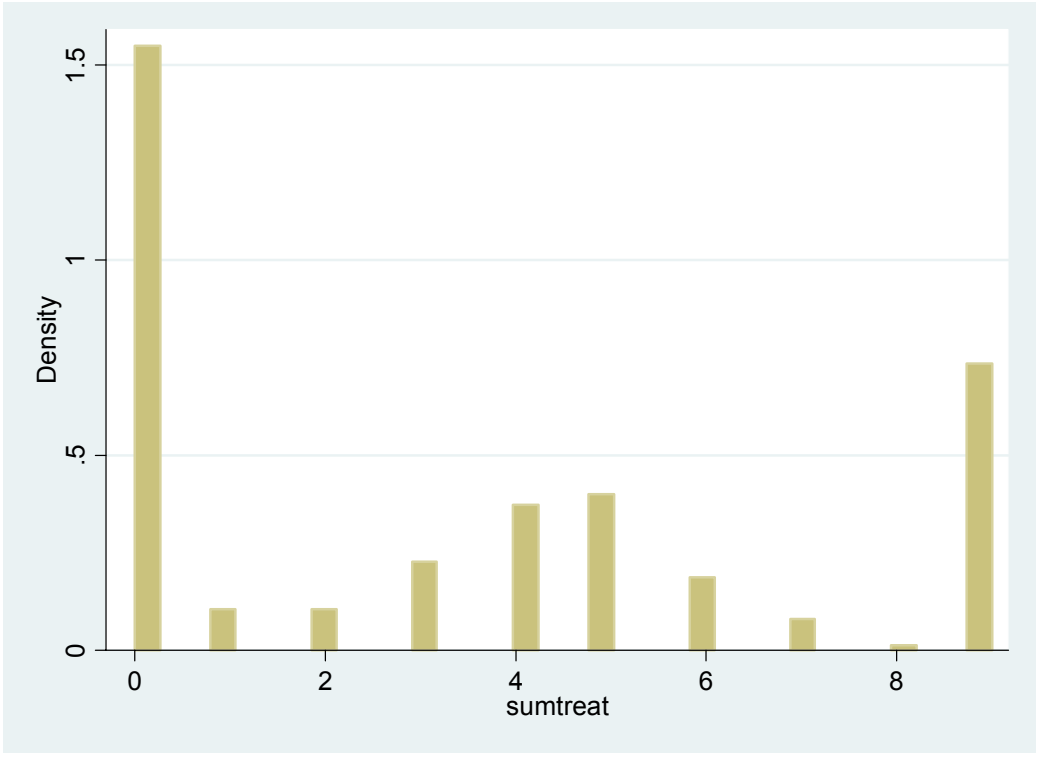

\section{The causal effect of grants on local spending and taxation}

To examine the causal effect of grants on local spending and local tax rates, we conduct a graphical analysis before turning to the econometric evidence.

\subsection{A graphical analysis}

As a starting point, we take a descriptive look at the data to examine if there is a change in the relationship between the outcome variables (i.e., local spending or local tax rates) and the net out-migration rate at the cut-off point of two percent in the net out-migration rate. ${ }^{14}$ This can give a first indication of whether we will be able to identify any effects via the grant formula.

We start by plotting the two outcome variables against net out-migration (i.e. only using raw correlations). In the left part of Figure 3 we present the correlation between local spending and the net out-migration rate and in the right part we present the correlation between local tax rates and the net out-migration rate. ${ }^{15}$ The left part of Figure 3 shows an increasing

\footnotetext{
${ }^{14}$ Since the cut-off point of two percent is only strict for the years 1996-1999, we will, for illustrative reasons, only use those years in the graphical analysis.

${ }^{15}$ Remember that we wouldn't expect a zero correlation between any of the two outcome variables and the net out-migration rate when looking at raw correlations - the IV method we use allows the historical net outmigration rate to have a direct impact on local spending and local tax rates. What we expect, is that the correlation is different before and after the cut-off point.
} 
relationship between local spending and historical net out-migration and the relationship seems to be like a spline-function, where the slope is steeper after a net out-migration rate of two percent. ${ }^{16}$ This pattern is not observed for the local tax rates (c.f. the right part of Figure 3). Even though there is an increasing relationship between the local tax rate and the net outmigration rate, there is no indication of a change in the steepness of the relationship beyond the cut-off line.

Figure 3. Outcome variables against net out-migration rate, raw correlations, 1996-1999
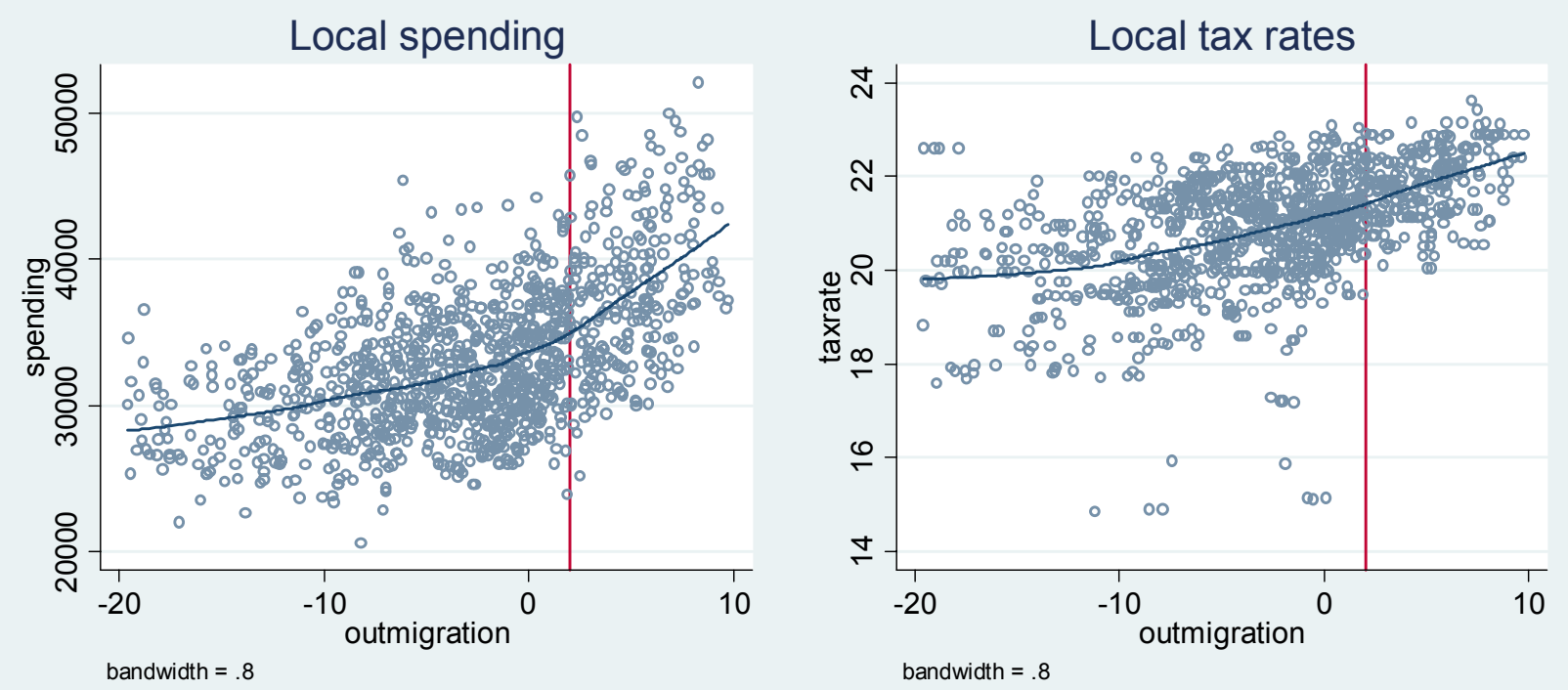

Our identifying assumption is that, once we have controlled for smooth functions of the outcome determining covariates, we have controlled for all direct effect of these covariates on the outcome. Any remaining relationship between the outcome variable and the net outmigration variable will then come from the grant formula, implying that there should be some action at an out-migration rate of two percent. To examine this, we estimate the second step equation (i.e., equation (5)), but leave out the predicted grants variable, and plot the residuals from that equation against net out-migration. What we would like to see is a zero relationship between the two variables for those municipalities that have not been treated (i.e., those municipalities with a net out-migration rate below two percent). We run the regression

\footnotetext{
${ }^{16}$ The vertical line in the figure is at a net out-migration rate of two percent. The estimated relationship is obtained through lowess smoothing, using the lowess command in STATA. Lowess carries out a locally weighted regression of the dependent variable on the net out-migration rate. In the figures, we have used the default bandwidth of 0.8 .
} 


$$
y_{i t}=\alpha+\beta f\left(m_{(i t-2)-(i t-12)}\right)+\varepsilon_{i t}
$$

where $y$ is either local spending or local tax rates and $f(\cdot)$ is up to a fourth-order polynomial in the historic out-migration rate. Equation (6) is similar to equation (5), but where we have excluded the grants variable and the smooth function in the change in the number of schoolage children (since we are only using the years 1996-1999). The relationship between the estimated residuals from equation (6) (with a fourth-order polynomial in the treatment determining covariate) and the net out-migration rate are displayed in Figure $4 .{ }^{17}$

Figure 4. Estimated residuals from equation (6), with a fourth-order polynomial in the net out-migration rate, against net out-migration rate, 1996-1999.
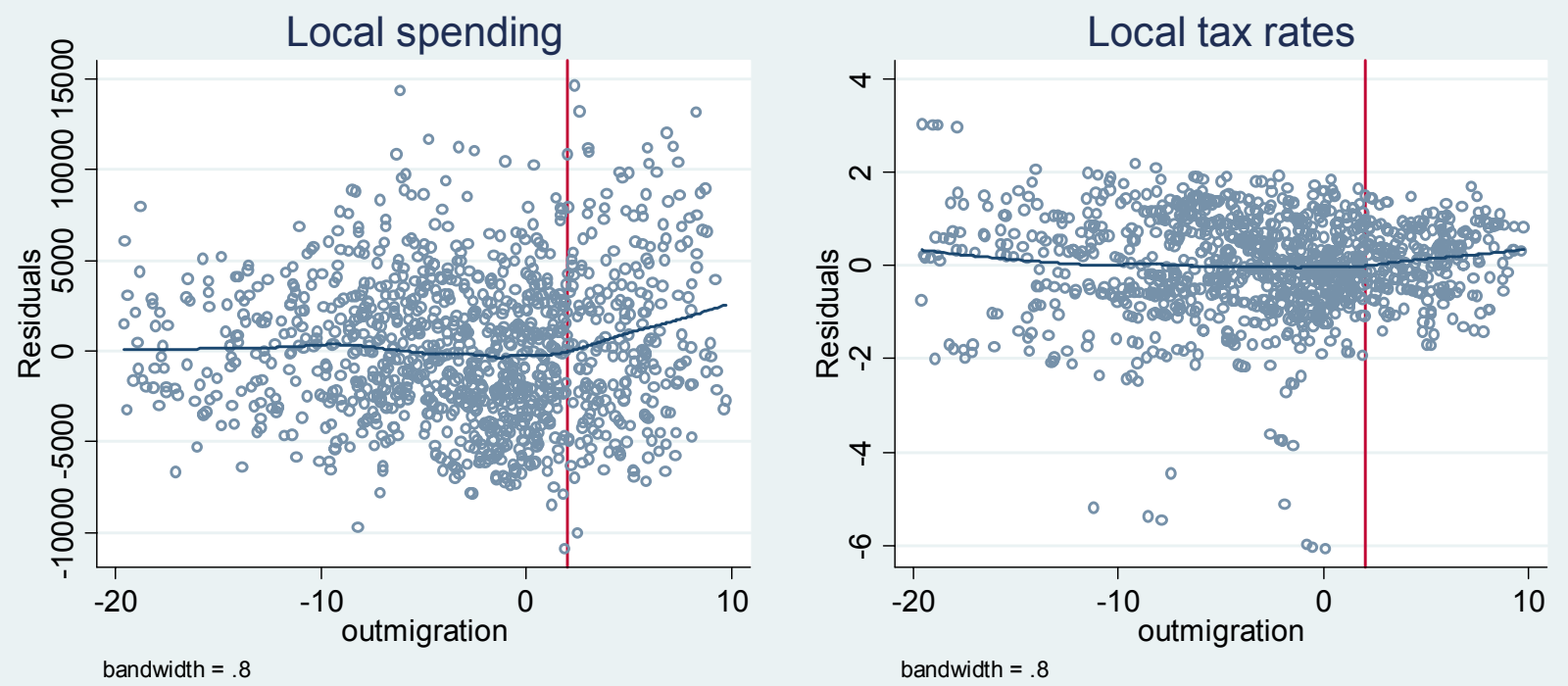

Figure 4 shows that there is more or less a zero relationship between spending and outmigration rate for those municipalities that have not been treated (i.e., those municipalities with a net out-migration rate below two percent). For the treated municipalities, however, there is a positive relationship between local spending and the net out-migration rate, from the

\footnotetext{
${ }^{17}$ In the figures, we show the relationship between the two variables for those municipalities with a net outmigration rate larger than -20 percent and lower than 10 percent. This constitutes the mass of the observations. The reason for excluding some municipalities with extreme out-migration rates is that they are so few and that the locally weighted regressions used in constructing the estimates in the figures are sensitive to the number of observations within the bandwidth. Graphs of residuals when we are using first-, second- and third-order polynomials in the treatment-determining covariate are presented in Figures A1-A3 in the Appendix.
} 
cut-off point of two percent. We interpret this as evidence that our control function is flexible enough to control for any direct effects of net out-migration on local spending, which validates our instrument. Turning to the tax rate residuals, there is no sign of change at an outmigration of two percent, suggesting a zero relationship for all out-migration rates.

Overall, the graphical analysis points at two interesting facts. First, it suggests a positive effect of grants on spending and no effect on tax rates. Second, it gives an indication that the instrument we use is valid conditional on a flexible functional form in the treatmentdetermining variable. For a more thorough investigation, we next turn to the econometric analysis.

\subsection{IV-estimates}

Below, we present the results from the first stage estimations to examine the relevance of the excluded instrument and the two-stage least squares (2SLS) estimates.

\subsubsection{First stage estimates}

The first stage estimates from the 2SLS procedure (i.e. estimation of equation (4)) are presented in Table 2, where total cost equalizing aid is regressed on the net migration aid and on a polynomial of the treatment-determining covariates. ${ }^{18}$ Each estimate/t-ratio-pair represents one regression. The estimates allow us to test whether the excluded instrument is relevant, by looking at the t-values for the grant formula (i.e. the exclusion restriction). In column i), we do not control for municipality-specific fixed effects, whereas these are included in column ii). ${ }^{19}$ In the top panel we control for a polynomial $\left(2^{\text {nd }}, 3^{\text {rd }}\right.$ and $4^{\text {th }}$ order $)$ of both net out-migration and change in the number of school-age children (measured as change in population aged 7-18), and in the bottom panel we specify the control function according to the composite rule (out-migration in years 1996-1999 and out-migration plus change in school-aged children for 2000-2004). The results using different specifications show that outmigration aid has a positive and statistically significant effect on total cost equalizing aid.

\footnotetext{
${ }^{18}$ We only report the first stage estimates for the baseline models. However, the results for the models estimated in the sensitivity analyses are very similar, with t-ratios clearly above 1.96 for the instrument.

${ }^{19}$ It is not clear from the literature whether on should control for municipality specific fixed effects or not. On the one side one could argue that given that we manage to capture any direct effects from the treatmentdetermining covariates in the control functions, fixed effects would not matter. On the other hand, the identifying variation will differ depending on whether fixed effects are controlled for or not; if fixed effects are excluded, both between and within variation are used, whereas only within variation is used when fixed effects are included.
} 
Thus, the requirement that the formula must affect grants received by the municipality is fulfilled and our instrument is relevant.

Table 2 First stage estimates (out-migration grant on total cost-equalizing grant).

Control functions

\begin{tabular}{cc}
\hline $2^{\text {nd }}$ order polynomial & $3.719 * * *$ \\
& $(0.251)$ \\
$3^{\text {rd }}$ order polynomial & $5.373 * * *$ \\
& $(0.472)$ \\
$4^{\text {th }}$ order polynomial & $6.507 * * *$ \\
& $(0.505)$
\end{tabular}

Control functions

$2^{\text {nd }}$ order polynomial

$3^{\text {rd }}$ order polynomial

$317 * * *$

0.303

$4^{\text {th }}$ order polynomial

$3.16 * * *$

0.314
$1.476 * * *$

(0.106)

$1.248 * * *$

$1.262 * * *$

(0.139)

\begin{tabular}{lcc}
\hline Time dummies & Yes & Yes \\
Fixed effects & No & Yes \\
No of observations & 2,538 & 2,538 \\
\hline Notes: Robust standard errors within parentheses. $* * *$ denotes significance at the $1 \%$ level.
\end{tabular}

\subsubsection{SLS estimates}

The second step estimates (estimations of equation (5)) are presented in Table 3 (spending) and Table 4 (taxes). As previously, we estimate the model both without (column i)) and with (column ii)) municipality-specific fixed effects. We control for a $2^{\text {nd }}, 3^{\text {rd }}$, or $4^{\text {th }}$ order polynomial in the treatment-determining covariates (i.e. in the top panel, out-migration, outmigration squared, change in students, change in students squared etc). Again, each estimate/t-ratio-pair corresponds to one regression.

All estimates in Table 3 are positive and significantly different from zero (in most cases they are significant at the one percent significance level). However, the estimated effects of grants on spending are considerably larger when we do not control for fixed effects; when using a $4^{\text {th }}$ order polynomial of the control function the effect is 1.3 when fixed effects are excluded and 0.76 when fixed effects are included. Also the effect diminishes when controlling for higher order polynomials. Finally, when the control function is set according to the composite rule, 
we find somewhat larger estimates. It can be noted that none of the estimates are significantly different from 1; that is, we cannot reject the null hypothesis that an increase in general grants with $1 \mathrm{SEK} /$ capita increases local spending with $1 \mathrm{SEK} /$ capita. In other words, we cannot reject the null hypothesis of full crowding-in of block grants.

Table 3 Effects of grants on local spending. 2SLS estimates.

\begin{tabular}{lcc}
\hline Control function & Net out-migration and change in population aged $7-18$ \\
\hline $2^{\text {nd }}$ order polynomial & $1.104^{* * *}$ & $1.488^{* * *}$ \\
& $(0.112)$ & $(0.274)$ \\
$3^{\text {rd }}$ order polynomial & $1.416^{* * *}$ & $0.837 * *$ \\
& $(0.142)$ & $(0.392)$ \\
$4^{\text {th }}$ order polynomial & $1.315^{* * *}$ & $0.760 *$ \\
& $(0.139)$ & $(0.409)$ \\
\hline Control function & \multicolumn{3}{c}{ Composite rule } \\
& $1.554^{* * *}$ & $1.52^{* * *}$ \\
$2^{\text {nd }}$ order polynomial & $(0.148)$ & $(0.183)$ \\
& $2.117^{* * *}$ & $1.437^{* * *}$ \\
$3^{\text {rd }}$ order polynomial & $(0.201)$ & $(0.193)$ \\
& $2.223^{* * *}$ & $1.436^{* * *}$ \\
$4^{\text {th }}$ order polynomial & $(0.213)$ & $(0.193)$ \\
& Yes & Yes \\
\hline Time dummies & No & Yes \\
Fixed effects & 2538 & 2538 \\
No of observations &,$* *$ and $*$ denotes significance at the 1,5 and $10 \%$ level.
\end{tabular}

Turning to the effects of grants on local tax rates, we see from Table 4 that the results are somewhat sensitive to whether we control for fixed effects or not; when not controlling for fixed effects we sometimes get significant effects (although very tiny) whereas the estimated effects are insignificant when controlling for fixed effects. However, since the significant effects are quantitatively close to zero we conclude that the results are consistent with the flypaper hypothesis that grants are not transmitted to lower taxes. 
Table 4 Effects of grants on local tax rate. 2SLS estimates.

\begin{tabular}{lcc}
\hline Control function & Net out-migration and change in population aged $7-18$ \\
\hline $2^{\text {nd }}$ order polynomial & $-0.0001 * * *$ & -0.00007 \\
& $(0.00004)$ & $(0.00005)$ \\
$3^{\text {rd }}$ order polynomial & $0.00008^{* *}$ & -0.00009 \\
& $(0.00004)$ & $(0.00007)$ \\
$4^{\text {th }}$ order polynomial & $0.0001^{* * *}$ & -0.0001 \\
& $(0.00003)$ & $(0.00007)$ \\
\hline Control function & \multicolumn{3}{c}{ Composite rule } \\
& $-8.31 \mathrm{e}-07$ & $4.25 \mathrm{e}-06$ \\
$2^{\text {nd }}$ order polynomial & $(0.00004)$ & $(0.00003)$ \\
& $0.0002^{* * *}$ & $-3.01 \mathrm{e}-06$ \\
$3^{\text {rd }}$ order polynomial & $(0.00004)$ & $(0.00003)$ \\
& $0.0002^{* * *}$ & 0.00001 \\
$4^{\text {th }}$ order polynomial & $(0.00004)$ & $(0.00003)$ \\
& Yes & Yes \\
Time dummies & No & Yes \\
Fixed effects & 2547 & 2547 \\
No of observations & Notes: Robust standard errors within parentheses. ${ }^{* * * * *}$ and $*$ denotes significance at the 1,5 and $10 \%$ level.
\end{tabular}

\subsubsection{Are the instruments valid?}

One underlying assumption for the above results to be valid is that the instruments are truly exogenous. The graphical analysis in Figure 4 supports this exogeneity assumption. Altonji et al. $(2002,2005)$ suggest an alternative way of testing the assumption. The idea is that if the results are insensitive to the inclusion of additional observed covariates, they are probably also insensitive to the inclusion of other (potentially unobserved) variables. In Table 5 (spending) and Table 6 (taxes) we present the 2SLS estimates when controlling for the municipal tax base, share of population of age $0-6$, share of population of age $7-15$, share of population 80 years and older, total population, and the share of population born abroad. The estimated effect of grants on spending is marginally lower, and somewhat less precisely estimated. The estimated effect of grants on local taxes is quite similar when we include the socio-economic control variables. We conclude that in all, the result supports the claim that the instrument is exogenous. 
Table 5 Effects of grants on local spending. 2SLS estimates, controlling for other covariates. Control function Net out-migration and change in population aged 7-18

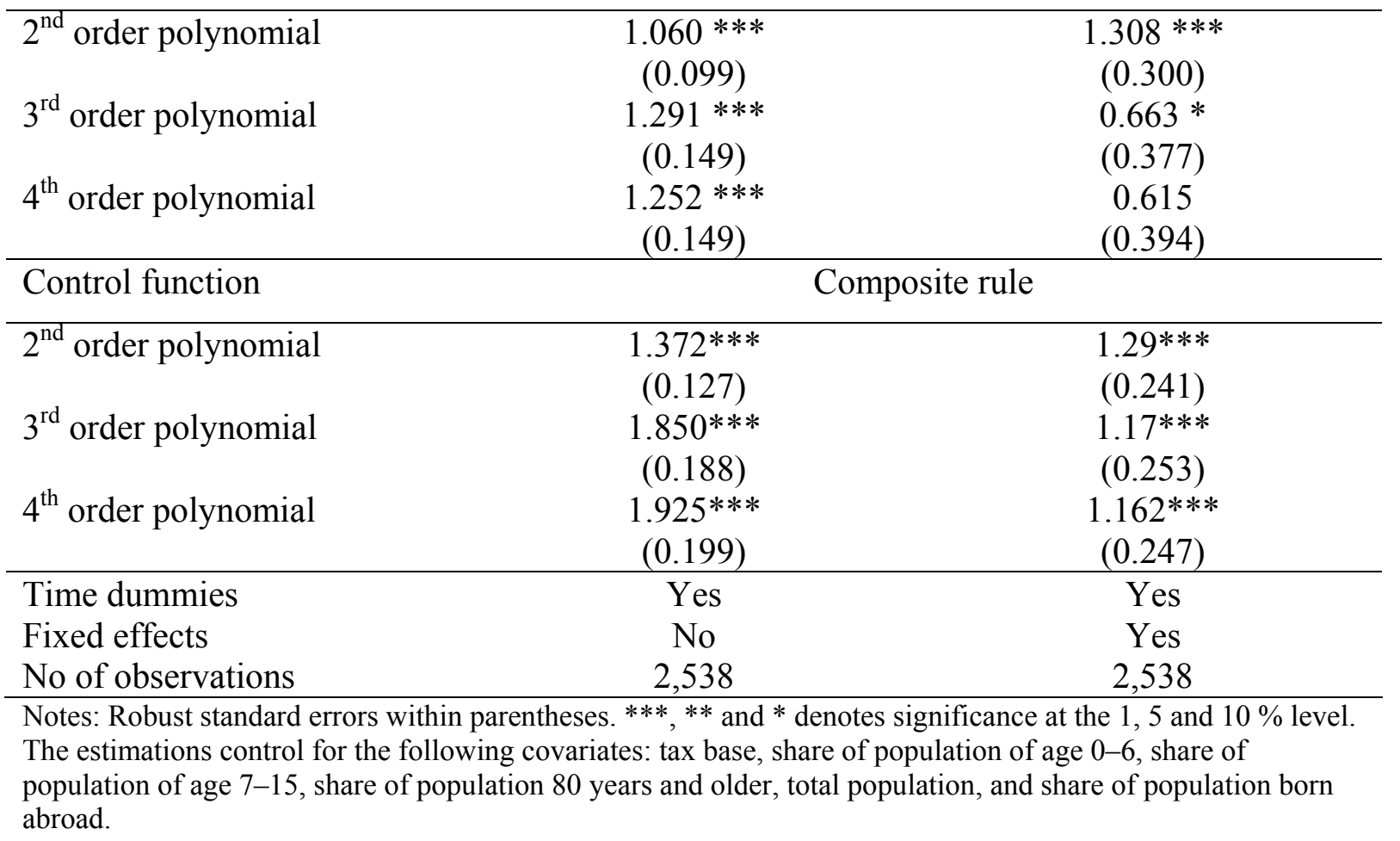

Table 6 Effects of grants on local tax rate. 2SLS estimates controlling for other covariates. Control function Net out-migration and change in population aged 7-18

\begin{tabular}{|c|c|c|}
\hline $2^{\text {nd }}$ order polynomial & $\begin{array}{l}-0.00002 \\
(0.00003)\end{array}$ & $\begin{array}{c}-0.00009 * \\
(0.00005)\end{array}$ \\
\hline $3^{\text {rd }}$ order polynomial & $\begin{array}{c}0.0001 * * * \\
(0.00004)\end{array}$ & $\begin{array}{c}-0.0002 * * \\
(0.00007)\end{array}$ \\
\hline $4^{\text {th }}$ order polynomial & $\begin{array}{c}0.0001 * * * \\
(0.00003)\end{array}$ & $\begin{array}{c}-0.00025 * * \\
(0.00007)\end{array}$ \\
\hline Control function & \multicolumn{2}{|c|}{ Composite rule } \\
\hline $2^{\text {nd }}$ order polynomial & $\begin{array}{l}0.00006^{*} \\
(0.00003)\end{array}$ & $\begin{array}{c}0.00005 \\
(0.00004)\end{array}$ \\
\hline $3^{\text {rd }}$ order polynomial & $\begin{array}{c}0.0002 * * * \\
(0.00004)\end{array}$ & $\begin{array}{c}0.00005 \\
(0.00004)\end{array}$ \\
\hline $4^{\text {th }}$ order polynomial & $\begin{array}{c}0.0002 * * * \\
(0.00005)\end{array}$ & $\begin{array}{c}0.00005 \\
(0.00004)\end{array}$ \\
\hline Time dummies & Yes & Yes \\
\hline Fixed effects & No & Yes \\
\hline No of observations & 2,547 & 2,547 \\
\hline
\end{tabular}




\subsubsection{Controlling for general autocorrelation in the error terms}

So far, we have assumed that the error terms are independently distributed. Earlier studies focusing on Swedish local governments have, however, shown that dynamics matter in local decision-making (see, e.g., Dahlberg \& Lindström, 1998; Dahlberg \& Johansson, 1998, 2000; Bergström et al, 2004). Hence, we re-estimate the models presented in Table 3 and Table 4, allowing for arbitrary serial correlation within municipality (see, e.g., Kézdi, 2002). ${ }^{20}$ The estimations are given in Table 7 (spending) and Table 8 (taxes). Allowing for potential autocorrelation in the errors yields, as expected, larger standard errors and, hence, lower significance. However, the effects of grants on spending are still statistically significant when not controlling for fixed effects and significant for the estimates controlling for fixed effects using a $2^{\text {nd }}$ or $4^{\text {th }}$ order polynomial in the top panel and for all polynomials in the bottom panel. Looking at taxes, the results are weaker when accounting for autocorrelation in the error terms, as compared to the baseline estimates. Since some of the estimates that earlier were statistically significant now have turned insignificant, this strengthens the conclusion that grants are not shifted into lower taxes,.

Table 7 Effects of grants on local spending. 2SLS estimates allowing for autocorrelation in the errors.

\begin{tabular}{|c|c|c|}
\hline Control function & \multicolumn{2}{|c|}{ Net out-migration and change in population aged $7-18$} \\
\hline $2^{\text {nd }}$ order polynomial & $\begin{array}{c}1.104 * * * \\
(0.209)\end{array}$ & $\begin{array}{c}1.488 * * * \\
(0.412)\end{array}$ \\
\hline $3^{\text {rd }}$ order polynomial & $\begin{array}{c}1.416 * * * \\
(0.235)\end{array}$ & $\begin{array}{c}0.837 \\
(0.624)\end{array}$ \\
\hline $4^{\text {th }}$ order polynomial & $\begin{array}{c}1.315 * * * \\
(0.223)\end{array}$ & $\begin{array}{l}0.760 * \\
(0.639)\end{array}$ \\
\hline Control function & \multicolumn{2}{|c|}{ Composite rule } \\
\hline $2^{\text {nd }}$ order polynomial & $\begin{array}{c}1.554 * * * \\
(0.282)\end{array}$ & $\begin{array}{l}1.52 * * * \\
(0.285)\end{array}$ \\
\hline $3^{\text {rd }}$ order polynomial & $\begin{array}{c}1.372 * * * \\
(0.227)\end{array}$ & $\begin{array}{c}1.437 * * * \\
(0.318)\end{array}$ \\
\hline $4^{\text {th }}$ order polynomial & $\begin{array}{c}2.117 * * * \\
(0.343)\end{array}$ & $\begin{array}{c}1.436 * * * \\
(0.315)\end{array}$ \\
\hline Time dummies & Yes & Yes \\
\hline Fixed effects & No & Yes \\
\hline No of observations & 2538 & 2538 \\
\hline
\end{tabular}

Notes: Robust standard errors clustered on cross-sectional units within parentheses. ***,** and * denotes significance at the 1,5 and $10 \%$ level.

\footnotetext{
${ }^{20}$ This is handled by clustering the standard errors at the municipality-level, using the clustering routine in STATA.
} 
Table 8 Effects of grants on local tax rate. 2SLS estimates allowing for autocorrelation in the errors.

\begin{tabular}{lcc}
\hline Control function & Net out-migration and change in population aged 7-18 \\
\hline $2^{\text {nd }}$ order polynomial & -0.0001 & -0.00007 \\
& $(0.00008)$ & $(0.00005)$ \\
$3^{\text {rd }}$ order polynomial & 0.00008 & -0.00009 \\
& $(0.00008)$ & $(0.00007)$ \\
$4^{\text {th }}$ order polynomial & $0.0001 *$ & -0.0001 \\
& $(0.00005)$ & $(0.00007)$ \\
\hline Control function & \multicolumn{2}{c}{ Composite rule } \\
\hline $2^{\text {nd }}$ order polynomial & $-8.31 \mathrm{e}-07$ & $4.25 \mathrm{e}-06$ \\
& $(0.00009)$ & $(0.00005)$ \\
$3^{\text {rd }}$ order polynomial & $0.0002 * * *$ & $-3.01 \mathrm{e}-06$ \\
& $(0.00007)$ & $(0.00005)$ \\
$4^{\text {th }}$ order polynomial & $0.0002 * * *$ & 0.00001 \\
& $(0.00007)$ & $(0.00005)$ \\
\hline Time dummies & Yes & Yes \\
Fixed effects & No & Yes \\
No of observations & 2547 & 2547 \\
\hline Notes: Robust standard errors clustered on cross-sectional units within parentheses. *** $* *$ and $*$ denotes \\
significance at the 1,5 and $10 \%$ level.
\end{tabular}

\section{Concluding remarks}

The paper investigates the causal effect of intergovernmental block grants on local public spending and taxes. Very few studies exist making a serious attempt at handling the possible endogeneity of grants. In this study we solve the endogeneity problem by using a discontinuity in the Swedish grant system. More precisely, we use an element of the grant system where only municipalities above a specific out-migration rate receive extra grants as an exclusion restriction in an IV-estimation. The analyses indicate that the instrument is both relevant and valid. The main conclusion is that we find evidence of crowding-in, where federal grants are shifted to more local spending, but not to reduced local taxes. Our results thus are consistent with a flypaper effect for Sweden.

The finding of a flypaper effect does not necessarily indicate irrational behavior of lower level governments. Rather, it seems realistic to assume that the existence of a flypaper effect depends on the fiscal institution studied. We study the integrated public sector in Sweden and argue that there may be a rational flypaper effect where federal government has better tax 
instruments than local governments while local governments has an advantage in service delivery. Modeling the flypaper effect under such a setting is a task for future research. Also, there is a need for more empirical work taking the likely endogeneity of federal grants seriously.

\section{References}

Altonji, J., Elder, T., and C. Taber (2002), “An Evaluation of Instrumental Variable Strategies for Estimating the Effects of Catholic Schools," NBER working paper 9358.

Altonji, J., Elder, T., and C. Taber (2005), "Selection on Observed and Unobserved: Assessing the Effectiveness of Catholic Schools," Journal of Political Economy 113, 151184.

Angrist, J. D. and V. Lavy (1999), "Using Maimonides' rule to estimate the effect of class size on scholastic achievement", The Quarterly Journal of Economics, 533-575.

Becker, E. (1996), “The illusion of fiscal illusion: Unsticking the flypaper effect”, Public Choice 86, 85-102.

Berg, E. and J. Rattsø (2006), "Do grants to regional governments stimulate regional development? A natural experiment approach”, mimeo, London School of Economics and Norwegian University of Science and Technology.

Bergström, P., M. Dahlberg and E. Mörk (2004), "The effect of grants and wages on municipal labour demand", Labour Economics 11, 315-334.

Besley, T. and A. Case (2000), "Unnatural Experiments? Estimating the Incidence of Endogenous Policies“, Economic Journal 110, F672-F694.

Bradford, D. and W. Oates, (1971a), "The Analysis of Revenue Sharing in a New Approach to Collective Fiscal Decisions“, Quarterly Journal of Economics 85(3). 
Bradford, D. and W. Oates, (1971b), “Towards a Predictive Theory of Intergovernmental Grants“, American Economic Review 61(2).

Dahlberg, M. and E. Johansson (1998), "The revenues-expenditures nexus: panel data evidence from Swedish municipalities", Applied Economics 30, 1379-1386.

Dahlberg, M. and E. Johansson (2000), “An examination of the dynamic behavior of local governments using GMM bootstrapping methods", Journal of Applied Econometrics 15, 401416.

Dahlberg, M. and T. Lindström (1998), “Are local governments governed by forward looking decision makers? An investigation of spending patterns in Swedish municipalities”, Journal of Urban Economics 44, 254-271.

Gamkhar, S. and W. Oates (1996), Asymmetries in the response to increases and decreases in intergovernmental grants: Some empirical findings, National Tax Journal 49, 501-512.

Gordon, N. (2004), "Do federal grants boost school spending? Evidence from Title I“, Journal of Public Economics 88(9-10), 1771-92.

Gramlich, E. (1977), "Intergovernmental grants: A review of the empirical literature", in W. Oates (ed.), The Political Economy of Fiscal Federalism, Lexington: D.C. Heath.

Guryan, J. (2003), "Does money matter? Estimates from education finance reform in Massachusetts“, mimeo, University of Chicago. An earlier version of the paper was published as NBER Working Paper No. 8269.

Hahn, J., P. Todd and W. Van der Klaauw (2001), "Identification and estimation of treatment effects with a regression-discontinuity design", Econometrica 69, 201-209.

Hines, J. R. and R. H. Thaler (1995), “Anomalies: The flypaper effect”, Journal of Economic Perspectives 9, 217-226. 
Johansson, E. (2003), 'Intergovernmental grants as a tactical instrument: Empirical evidence from Swedish municipalities", Journal of Public Economics 87, 883-915.

Kézdi, G. (2002), "Robust standard errors estimation in fixed-effects panel models", mimeo, University of Michigan.

Knight, B. (2002), "Endogenous federal grants and crowd-out of state government spending: Theory and evidence from the federal highway aid program," American Economic Review 92 $1,71-92$.

Lee, D. (2005), "Randomized experiments from non-random selection in the US House elections", forthcoming in Journal of Econometrics.

Scott, A. (1952), “The evaluation of federal grants”, Economica 19, 377-394.

Turnbull, G. (1998), "The overspending and flypaper effects of fiscal illusion: Theory and empirical evidence", Journal of Urban Economics 44, 1.26. 


\section{Appendix}

Figure A1. Estimated residuals from equation (6), with a first-order polynomial in the net out-migration rate, against net out-migration rate, 1996-1999.
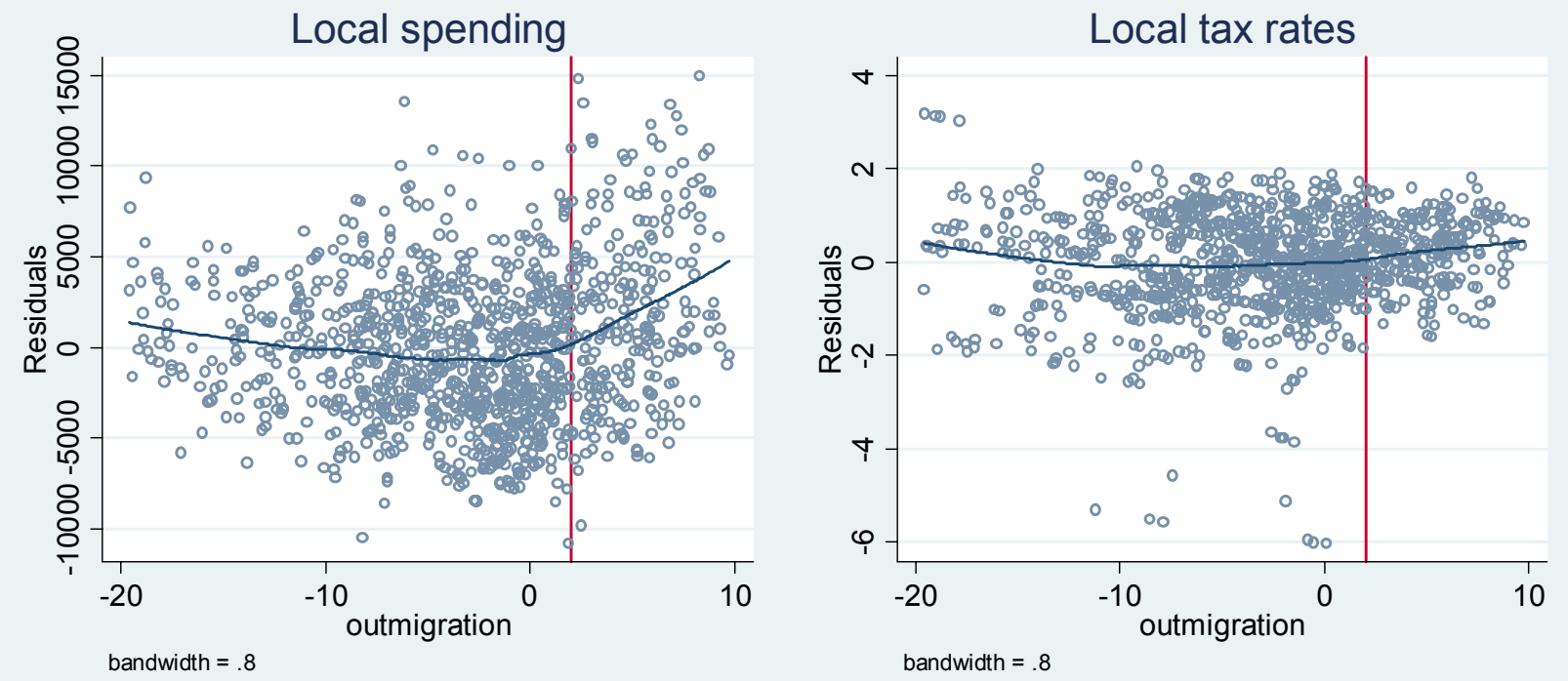

Figure A2. Estimated residuals from equation (6), with a second-order polynomial in the net out-migration rate, against net out-migration rate, 1996-1999.
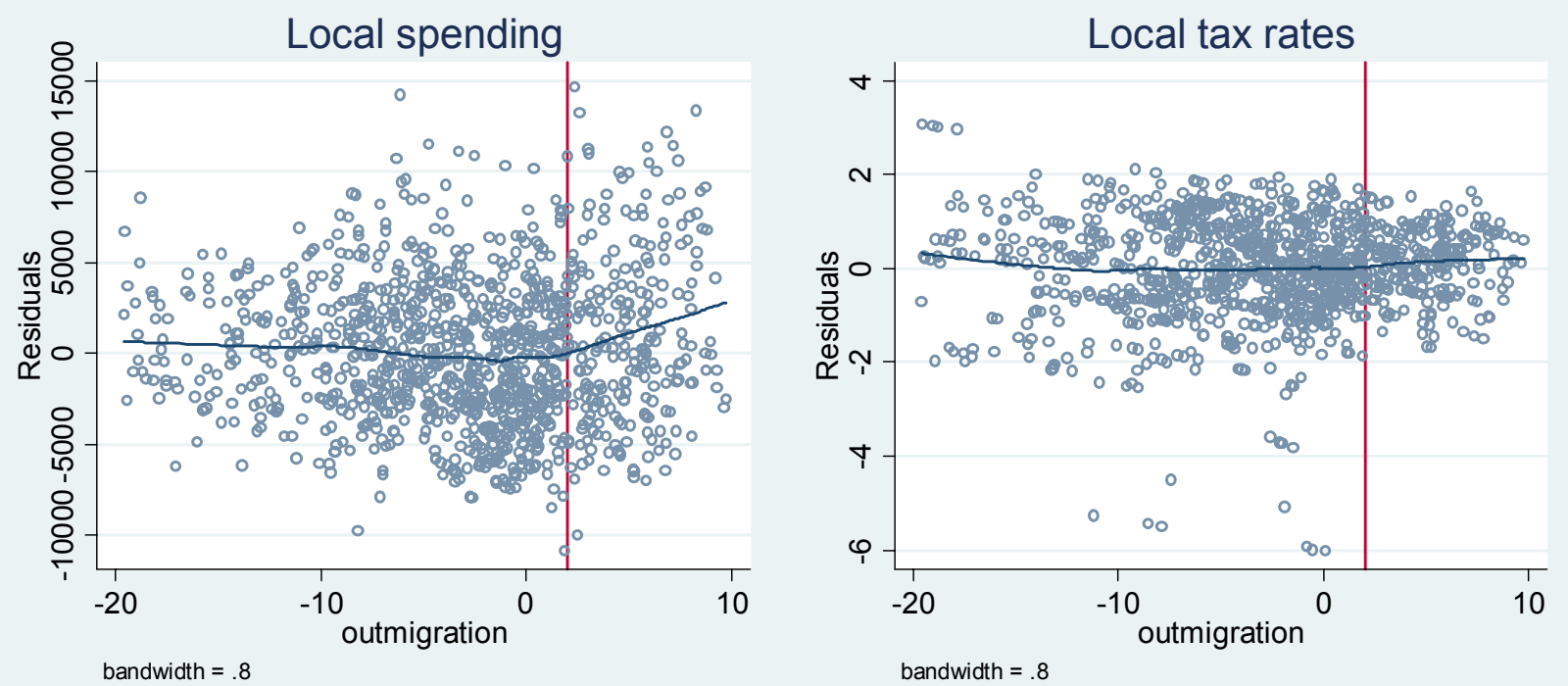
Figure A3. Estimated residuals from equation (6), with a third-order polynomial in the net out-migration rate, against net out-migration rate, 1996-1999.
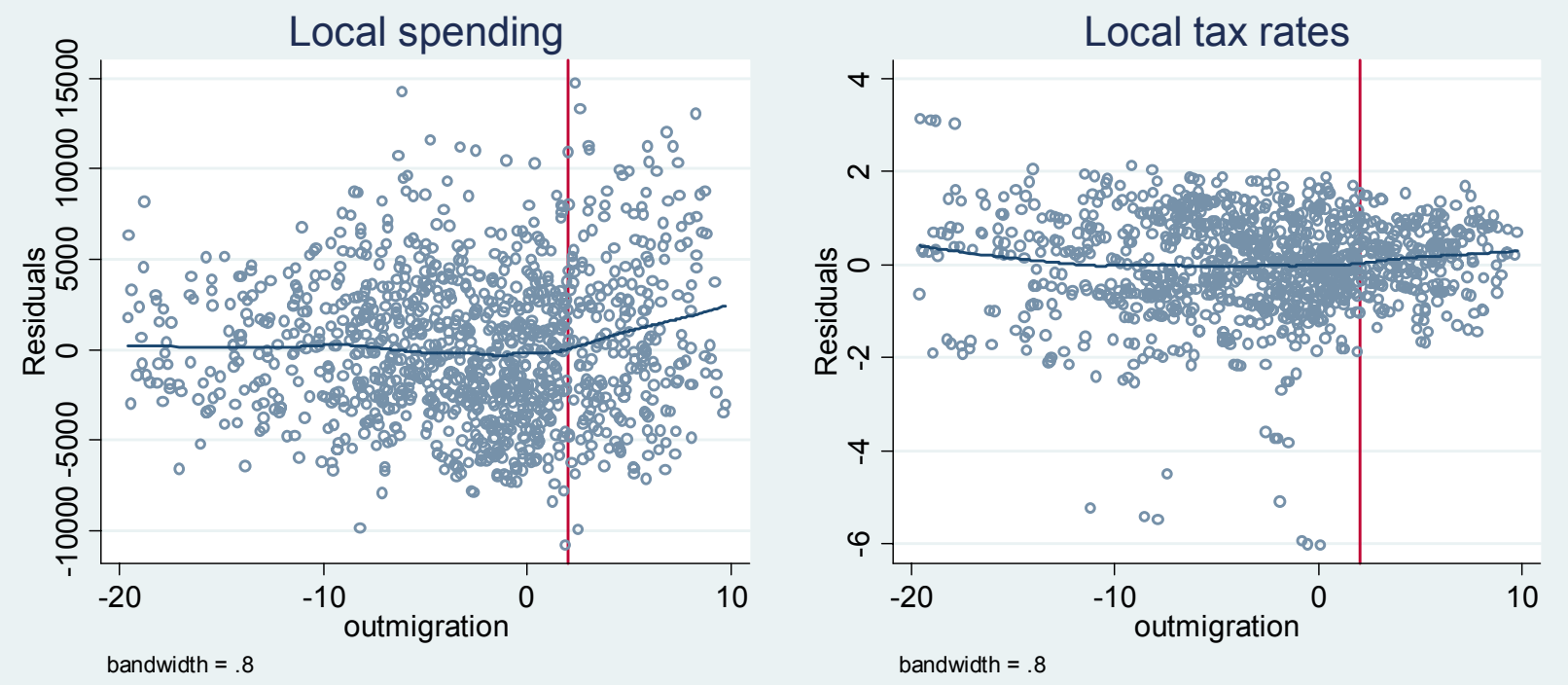


\section{CESifo Working Paper Series}

(for full list see www.cesifo-group.de)

1796 Louis Eeckhoudt, Béatrice Rey and Harris Schlesinger, A Good Sign for Multivariate Risk Taking, September 2006

1797 Dominique M. Gross and Nicolas Schmitt, Why do Low- and High-Skill Workers Migrate? Flow Evidence from France, September 2006

1798 Dan Bernhardt, Stefan Krasa and Mattias Polborn, Political Polarization and the Electoral Effects of Media Bias, September 2006

1799 Pierre Pestieau and Motohiro Sato, Estate Taxation with Both Accidental and Planned Bequests, September 2006

1800 Øystein Foros and Hans Jarle Kind, Do Slotting Allowances Harm Retail Competition?, September 2006

1801 Tobias Lindhe and Jan Södersten, The Equity Trap, the Cost of Capital and the Firm's Growth Path, September 2006

1802 Wolfgang Buchholz, Richard Cornes and Wolfgang Peters, Existence, Uniqueness and Some Comparative Statics for Ratio- and Lindahl Equilibria: New Wine in Old Bottles, September 2006

1803 Jan Schnellenbach, Lars P. Feld and Christoph Schaltegger, The Impact of Referendums on the Centralisation of Public Goods Provision: A Political Economy Approach, September 2006

1804 David-Jan Jansen and Jakob de Haan, Does ECB Communication Help in Predicting its Interest Rate Decisions?, September 2006

1805 Jerome L. Stein, United States Current Account Deficits: A Stochastic Optimal Control Analysis, September 2006

1806 Friedrich Schneider, Shadow Economies and Corruption all over the World: What do we really Know?, September 2006

1807 Joerg Lingens and Klaus Waelde, Pareto-Improving Unemployment Policies, September 2006

1808 Axel Dreher, Jan-Egbert Sturm and James Raymond Vreeland, Does Membership on the UN Security Council Influence IMF Decisions? Evidence from Panel Data, September 2006

1809 Prabir De, Regional Trade in Northeast Asia: Why do Trade Costs Matter?, September 2006 
1810 Antonis Adam and Thomas Moutos, A Politico-Economic Analysis of Minimum Wages and Wage Subsidies, September 2006

1811 Guglielmo Maria Caporale and Christoph Hanck, Cointegration Tests of PPP: Do they also Exhibit Erratic Behaviour?, September 2006

1812 Robert S. Chirinko and Hisham Foad, Noise vs. News in Equity Returns, September 2006

1813 Oliver Huelsewig, Eric Mayer and Timo Wollmershaeuser, Bank Behavior and the Cost Channel of Monetary Transmission, September 2006

1814 Michael S. Michael, Are Migration Policies that Induce Skilled (Unskilled) Migration Beneficial (Harmful) for the Host Country?, September 2006

1815 Eytan Sheshinski, Optimum Commodity Taxation in Pooling Equilibria, October 2006

1816 Gottfried Haber and Reinhard Neck, Sustainability of Austrian Public Debt: A Political Economy Perspective, October 2006

1817 Thiess Buettner, Michael Overesch, Ulrich Schreiber and Georg Wamser, The Impact of Thin-Capitalization Rules on Multinationals' Financing and Investment Decisions, October 2006

1818 Eric O’N. Fisher and Sharon L. May, Relativity in Trade Theory: Towards a Solution to the Mystery of Missing Trade, October 2006

1819 Junichi Minagawa and Thorsten Upmann, Labor Supply and the Demand for Child Care: An Intertemporal Approach, October 2006

1820 Jan K. Brueckner and Raquel Girvin, Airport Noise Regulation, Airline Service Quality, and Social Welfare, October 2006

1821 Sijbren Cnossen, Alcohol Taxation and Regulation in the European Union, October 2006

1822 Frederick van der Ploeg, Sustainable Social Spending in a Greying Economy with Stagnant Public Services: Baumol’s Cost Disease Revisited, October 2006

1823 Steven Brakman, Harry Garretsen and Charles van Marrewijk, Cross-Border Mergers \& Acquisitions: The Facts as a Guide for International Economics, October 2006

1824 J. Atsu Amegashie, A Psychological Game with Interdependent Preference Types, October 2006

1825 Kurt R. Brekke, Ingrid Koenigbauer and Odd Rune Straume, Reference Pricing of Pharmaceuticals, October 2006

1826 Sean Holly, M. Hashem Pesaran and Takashi Yamagata, A Spatio-Temporal Model of House Prices in the US, October 2006 
1827 Margarita Katsimi and Thomas Moutos, Inequality and the US Import Demand Function, October 2006

1828 Eytan Sheshinski, Longevity and Aggregate Savings, October 2006

1829 Momi Dahan and Udi Nisan, Low Take-up Rates: The Role of Information, October 2006

1830 Dieter Urban, Multilateral Investment Agreement in a Political Equilibrium, October 2006

1831 Jan Bouckaert and Hans Degryse, Opt In Versus Opt Out: A Free-Entry Analysis of Privacy Policies, October 2006

1832 Wolfram F. Richter, Taxing Human Capital Efficiently: The Double Dividend of Taxing Non-qualified Labour more Heavily than Qualified Labour, October 2006

1833 Alberto Chong and Mark Gradstein, Who's Afraid of Foreign Aid? The Donors' Perspective, October 2006

1834 Dirk Schindler, Optimal Income Taxation with a Risky Asset - The Triple Income Tax, October 2006

1835 Andy Snell and Jonathan P. Thomas, Labour Contracts, Equal Treatment and WageUnemployment Dynamics, October 2006

1836 Peter Backé and Cezary Wójcik, Catching-up and Credit Booms in Central and Eastern European EU Member States and Acceding Countries: An Interpretation within the New Neoclassical Synthesis Framework, October 2006

1837 Lars P. Feld, Justina A.V. Fischer and Gebhard Kirchgaessner, The Effect of Direct Democracy on Income Redistribution: Evidence for Switzerland, October 2006

1838 Michael Rauscher, Voluntary Emission Reductions, Social Rewards, and Environmental Policy, November 2006

1839 Vincent Vicard, Trade, Conflicts, and Political Integration: the Regional Interplays, November 2006

1840 Erkki Koskela and Mikko Puhakka, Stability and Dynamics in an Overlapping Generations Economy under Flexible Wage Negotiation and Capital Accumulation, November 2006

1841 Thiess Buettner, Michael Overesch, Ulrich Schreiber and Georg Wamser, Taxation and Capital Structure Choice - Evidence from a Panel of German Multinationals, November 2006

1842 Guglielmo Maria Caporale and Alexandros Kontonikas, The Euro and Inflation Uncertainty in the European Monetary Union, November 2006 
1843 Jan K. Brueckner and Ann G. Largey, Social Interaction and Urban Sprawl, November 2006

1844 Eytan Sheshinski, Differentiated Annuities in a Pooling Equilibrium, November 2006

1845 Marc Suhrcke and Dieter Urban, Are Cardiovascular Diseases Bad for Economic Growth?, November 2006

1846 Sam Bucovetsky and Andreas Haufler, Preferential Tax Regimes with Asymmetric Countries, November 2006

1847 Luca Anderlini, Leonardo Felli and Andrew Postlewaite, Should Courts always Enforce what Contracting Parties Write?, November 2006

1848 Katharina Sailer, Searching the eBay Marketplace, November 2006

1849 Paul De Grauwe and Pablo Rovira Kaltwasser, A Behavioral Finance Model of the Exchange Rate with Many Forecasting Rules, November 2006

1850 Doina Maria Radulescu and Michael Stimmelmayr, ACE vs. CBIT: Which is Better for Investment and Welfare?, November 2006

1851 Guglielmo Maria Caporale and Mario Cerrato, Black Market and Official Exchange Rates: Long-Run Equilibrium and Short-Run Dynamics, November 2006

1852 Luca Anderlini, Leonardo Felli and Andrew Postlewaite, Active Courts and Menu Contracts, November 2006

1853 Andreas Haufler, Alexander Klemm and Guttorm Schjelderup, Economic Integration and Redistributive Taxation: A Simple Model with Ambiguous Results, November 2006

1854 S. Brock Blomberg, Thomas DeLeire and Gregory D. Hess, The (After) Life-Cycle Theory of Religious Contributions, November 2006

1855 Albert Solé-Ollé and Pilar Sorribas-Navarro, The Effects of Partisan Alignment on the Allocation of Intergovernmental Transfers. Differences-in-Differences Estimates for Spain, November 2006

1856 Biswa N. Bhattacharyay, Understanding the Latest Wave and Future Shape of Regional Trade and Cooperation Agreements in Asia, November 2006

1857 Matz Dahlberg, Eva Mörk, Jørn Rattsø and Hanna Ågren, Using a Discontinuous Grant to Identify the Effect of Grants on Local Taxes and Spending, November 2006 